IRA-International Journal of Management \& Social Sciences

ISSN 2455-2267; Vol.04, Issue 02 (2016)

Pg. no. 502-511

Institute of Research Advances

http://research-advances.org/index.php/RAJMSS

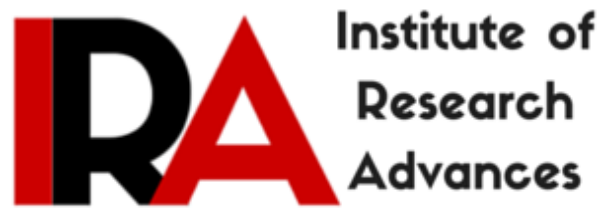

\title{
Factors Influencing Respondents Opting for Agro Based Food Industries in Theni District
}

\author{
A. Sagaya Nambikai Mary ${ }^{1}$ and S. Maria John ${ }^{2}$ \\ ${ }^{1}$ Research Scholar Mother Teresa Women's University, Kodaikanal, India. \\ ${ }^{2}$ Principal, Annai Velankanni College, Tholayavattam, India.
}

Type of Review: Peer Reviewed.

DOI: http://dx.doi.org/10.21013/jmss.v4.n2.p21

\section{How to cite this paper:}

Mary, A., \& John, S. (2016). Factors Influencing Respondents Opting for Agro Based Food Industries in Theni District. IRA-International Journal of Management \& Social Sciences (ISSN 2455-2267), 4(2), 502-511. doi:http://dx.doi.org/10.21013/jmss.v4.n2.p21

(C) Institute of Research Advances

\section{(cc) EY-NC}

This work is licensed under a Creative Commons Attribution-Non Commercial 4.0 International License subject to proper citation to the publication source of the work.

Disclaimer: The scholarly papers as reviewed and published by the Institute of Research Advances (IRA) are the views and opinions of their respective authors and are not the views or opinions of the IRA. The IRA disclaims of any harm or loss caused due to the published content to any party. 


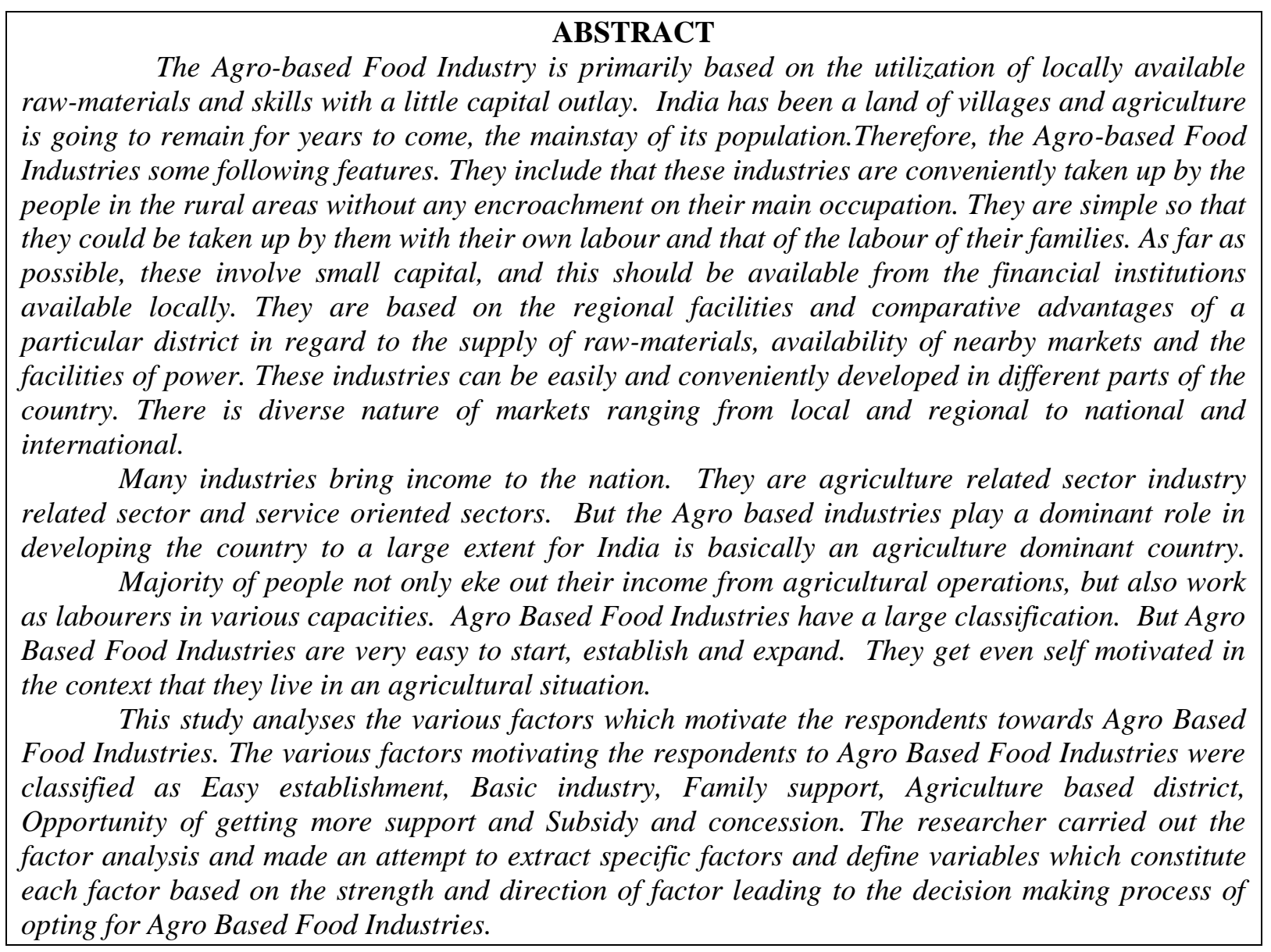

\section{Keywords}

Agro-based Food Industries, Motivating Factors, Basic Industry, Subsidy and concession.

\section{Introduction}

The Agro-based Food Industry is primarily based on the utilization of locally available rawmaterials and skills with a little capital outlay. India has been a land of villages and agriculture is going to remain for years to come, the mainstay of its population.Therefore, the Agro-based Food Industries some following features. They include that these industries are conveniently taken up by the people in the rural areas without any encroachment on their main occupation. They are simple so that they could be taken up by them with their own labour and that of the labour of their families. As far as possible, these involve small capital, and this should be available from the financial institutions available locally. They are based on the regional facilities and comparative advantages of a particular district in regard to the supply of raw-materials, availability of nearby markets and the facilities of power. These industries can be easily and conveniently developed in different parts of the country. There is diverse nature of markets ranging from local and regional to national and international.

Many industries bring income to the nation. They are agriculture related sector industry related sector and service oriented sectors. But the Agro based industries play a dominant role in developing the country to a large extent for India is basically an agriculture dominant country.

Majority of people not only eke out their income from agricultural operations, but also work as labourers in various capacities. Agro Based Food Industries have a large classification. But Agro Based Food Industries are very easy to start, establish and expand. They get even self motivated in the context that they live in an agricultural situation. 
This study analyses the various factors which motivate the respondents towards Agro Based Food Industries. The various factors motivating the respondents to Agro Based Food Industries were classified as Easy establishment, Basic industry, Family support, Agriculture based district, Opportunity of getting more support and Subsidy and concession. The researcher carried out the factor analysis and made an attempt to extract specific factors and define variables which constitute each factor based on the strength and direction of factor leading to the decision making process of opting for Agro Based Food Industries. Kamta Prasad in his study entitled, "Poverty Alleviation Shift in Paradigms", stressed that there is a need for an occupational diversification, by increasing rural industries and support so as to enable the weaker sections to derive maximum benefits. The rural industries can compete with the modern large scale industries only through development of infrastructural facilities and support system. ${ }^{1}$ Nair B.C. and Oscar D. Medo in their study entitled "Food Processing Industry: A Catalyst to Goa's Ailing Agricultural sector" has revealed that there is a round the year poor sales for bakery products, beverages, wine and liquor, packaged water, canned fish, fruits, dairy products - milk, ice cream, butter, cheese, masalas etc. As per National Sample Survey and $55^{\text {th }}$ round Common Expenditure Survey, the average monthly per capita expenditure of Goa is much higher than the national average. It is also pertinent to note that in Goa people spend more on food items than on non food items. ${ }^{2}$ Raghuramaiah B in his study entitled, "Indian Food Regulations in the Global context" has described that effect of globalization of food trade on the Indian food regulatory system are considered with respect to food safety, consumer protection, restrictive policies on additives and pesticide residues, the definition of natural and artificial codex alimentations commission rulings, FDA regulations and the need to improve both the health of the Indian population (via improved drinking water, post harvest technologies) and inward investment in the Indian Food industry. ${ }^{3}$ Ramanujam K. in his study entitled, "Agro- processing industry in Economic Development" has revealed that the role played by agro- processing industries in our economy has multiple facets and it changes the course of development. There is a vast scope for development of agro- industries in India. India should develop agro- processing industry as a sector of economy in a top priority. ${ }^{4}$ Reddy Y. G. in his article study entitled, "Role of melas in Marketing Agro Industrial products", has aimed at exploring the practical problem faced by the producers participating in the mela and the customers who buy the products. The study observed that the melas were considered as an effective strategy for marketing. ${ }^{5}$

\section{Methodology}

The objective of the study is to examine the factors that motivated the respondents to select the Agro Based Food Industries. Theni district was selected as it is agriculture based district. This study is an empirical research, based on the survey method. First-hand data required for the study were collected from the respondents directly by the researcher herself. The data relating to the customers were collected with the help of an Interview Schedule.

Secondary data have been collected from the published and unpublished records of the offices of the Department of Agriculture, the NABARD, Government of India and Publications, Action Plan of the DIC, Journals, Bulletins, Magazines and Reports of the Assistant Director of Statistics, Theni.

An interview schedule was prepared by the researcher for collecting the necessary data. Before preparing the schedule, the researcher made a comprehensive review of the literature directly and indirectly connected with the topic of the study.

A field survey has been conducted covering 350 sample Agro Based Food Industrial units of the eight blocks and six municipalities of the district. The Proportionate Random Sampling method has been used. Five categories of agro food industries namely Rice and Flour mills, Vegetable and Fruit Processing units and Bread making and Confectionaries are prominent in the district. Twenty five per cent of each of these categories of food industries is taken for the study.

\section{Factor Analysis}

In this analysis, each variable is expressed as a linear combination of under-lying factors. The amount of variance, which a variable shares with all the other variables included in the analysis, is referred to as communality. The co-variation among the variables is described in terms of a small 
number of common factors plus a unique factor for each variable. If the variables are standardised, the factor model may be represented as:

Where,

$$
X_{i}=A_{i j} F_{1}+A_{i 2} F_{2}+A_{i 3} F_{3}+\ldots \ldots . . A_{i m} F_{m}+V_{i} U_{i}
$$

$X_{i}=i^{\text {th }}$ standardised variable

$\mathrm{A}_{\mathrm{ij}}=$ Standardised multiple regression co-efficient of.

Variable ' $\mathrm{i}$ ' on common factor ' $\mathrm{j}$ '

$\mathrm{F}=$ Common factor

$\mathrm{V}_{\mathrm{i}}=$ Standardised regression co-efficient of variable ' $\mathrm{i}$ ' on unique factor

$\mathrm{U}_{\mathrm{i}}=$ the Unique factor for variable ' $\mathrm{i}$ '

$\mathrm{M}=$ Number of common factor

The unique factors are not correlated with each other and the common factors themselves can be expressed as linear combinations of the observed variables.

Where,

$$
\mathrm{F}_{\mathrm{i}}=\mathrm{W}_{\mathrm{i} 1} \mathrm{X}_{1}+\mathrm{W}_{\mathrm{i} 2} \mathrm{X}_{2}+\mathrm{W}_{\mathrm{i} 3} \mathrm{X}_{3}+\ldots . .+\mathrm{W}_{\mathrm{ik}}+\mathrm{X}_{\mathrm{k}}
$$

$\mathrm{Fi}=$ Estimate of $\mathrm{i}^{\text {th }}$ factor score co-efficient

$\mathrm{Wi}=$ Weight of factor score co-efficient

$\mathrm{K}=$ Number of variables

It is possible to select a weight or factor score co-efficient, so that the first factor explains the largest portion of the total variance. Then a second set of weights can be selected, so that the second factor accounts for most of the residual variance, subject to not being correlated with the first factor. The same principle could be applied for selecting additional weights for the additional factors. Thus the factors can be estimated so that their factor scores, unlike the value of the original value, are not correlated. Furthermore, the first factor accounts for the highest variance in the data, the second highest and so on.

\section{Rotated Factor Matrix for Factors Motivating Respondents to Agro Based Food Industries}

The Rotated Factor Matrix for factors motivating respondents towards Agro Based Food Industries is given in Table 1 .

TABLE 1

Rotated Factors Matrix for Factors Motivating Respondents towards Agro Based Food

\begin{tabular}{|c|l|c|c|c|c|c|c|}
\hline Sl. & \multicolumn{1}{|c|}{ Variable } & \multicolumn{5}{|c|}{} & \multicolumn{5}{|c|}{ No } & \multicolumn{1}{|c|}{$\mathbf{1}$} & $\mathbf{2}$ & $\mathbf{3}$ & $\mathbf{4}$ & $\mathbf{5}$ & $\mathbf{6}$ \\
\cline { 2 - 7 } 1. & $\begin{array}{l}\text { Developing an } \\
\text { ABFI is easy }\end{array}$ & .823 & .105 & .238 & .032 & .072 & .074 \\
\hline 2. & $\begin{array}{l}\text { Minimum legal } \\
\text { formalities are } \\
\text { required }\end{array}$ & .797 & .287 & .009 & .090 & .134 & .132 \\
\hline 3. & $\begin{array}{l}\text { There is nearness to } \\
\text { transport and raw } \\
\text { materials }\end{array}$ & .765 & .209 & .144 & .196 & .251 & .089 \\
\hline 4. & $\begin{array}{l}\text { Access to cheap } \\
\text { labour and } \\
\text { technology }\end{array}$ & .653 & .357 & .023 & .085 & .011 & .153 \\
\hline 5. & $\begin{array}{l}\text { More demand for } \\
\text { goods }\end{array}$ & .251 & .749 & .087 & .028 & .029 & .069 \\
\hline 6. & Basic industry & .362 & .680 & .248 & .430 & .068 & .082 \\
\hline
\end{tabular}

Industries 


\begin{tabular}{|c|c|c|c|c|c|c|c|}
\hline & $\begin{array}{l}\text { goods are needed } \\
\text { regularly }\end{array}$ & & & & & & \\
\hline 7. & $\begin{array}{l}\text { All categories of } \\
\text { people need them }\end{array}$ & .061 & .578 & .042 & .319 & .196 & .489 \\
\hline 8. & $\begin{array}{l}\text { Easy pricing of } \\
\text { goods }\end{array}$ & .185 & .508 & .258 & .192 & .186 & .202 \\
\hline 9. & $\begin{array}{l}\text { ABFI are family } \\
\text { based industries }\end{array}$ & .112 & .215 & .824 & .162 & .226 & .259 \\
\hline 10. & $\begin{array}{l}\text { Family members } \\
\text { are employed }\end{array}$ & .105 & .043 & .685 & .123 & .179 & .349 \\
\hline 11. & $\begin{array}{l}\text { Avoidance of } \\
\text { unnecessary } \\
\text { expenses }\end{array}$ & .068 & .127 & .659 & .046 & .198 & .037 \\
\hline 12. & $\begin{array}{l}\text { Speedy } \\
\text { development of } \\
\text { business }\end{array}$ & .047 & .072 & .538 & .089 & .083 & .015 \\
\hline 13. & $\begin{array}{l}\text { Location of ABFI } \\
\text { are made locally }\end{array}$ & .273 & .069 & .006 & .779 & .145 & 075 \\
\hline 14. & $\begin{array}{l}\text { Availability of raw } \\
\text { materials }\end{array}$ & .411 & .259 & .279 & .633 & .323 & .176 \\
\hline 15. & $\begin{array}{l}\text { More assistance } \\
\text { from district head } \\
\text { quarters }\end{array}$ & .247 & .157 & .001 & .632 & .192 & .182 \\
\hline 16. & $\begin{array}{l}\text { Numerous } \\
\text { assistance to ABFIs }\end{array}$ & .322 & .024 & . 180 & .096 & .847 & .078 \\
\hline 17. & $\begin{array}{l}\text { Support based on } \\
\text { standard of living }\end{array}$ & .142 & .195 & .280 & .266 & .703 & .020 \\
\hline 18. & $\begin{array}{l}\text { Category based } \\
\text { support }\end{array}$ & .133 & .314 & .401 & .277 & .517 & .009 \\
\hline 19. & $\begin{array}{l}\text { Numerous types of } \\
\text { subsidy to food } \\
\text { industries }\end{array}$ & .280 & .135 & .135 & .091 & .000 & .829 \\
\hline 20. & $\begin{array}{l}\text { Caste wise } \\
\text { allocation of } \\
\text { subsidy }\end{array}$ & .156 & .436 & .104 & .096 & .010 & .668 \\
\hline 21. & $\begin{array}{l}\text { Concession at all } \\
\text { times }\end{array}$ & .074 & .325 & .019 & .082 & .099 & .543 \\
\hline
\end{tabular}

Extract Method Principal Component Analysis 202,

Rotation Method: Varimax with Kaiser Normalization 259,

a. Rotation converged in 20 iterations 349 
TABLE 2

CAUSES RELATING TO SELECT AGRO BASED FOOD INDUSTRIES

\begin{tabular}{|c|c|c|c|}
\hline $\begin{array}{l}\text { Sl. } \\
\text { No }\end{array}$ & Causes & $\begin{array}{c}\text { Factor } \\
\text { Loadings }\end{array}$ & Communality \\
\hline 1 & $\begin{array}{l}\text { Easy Establishment } \\
\text { Developing an AGFI is easy }\end{array}$ & .823 & .790 \\
\hline 2 & Minimum legal formalities are required & .797 & .689 \\
\hline 3 & $\begin{array}{l}\text { There is nearness to transport and raw } \\
\text { materials }\end{array}$ & .765 & .662 \\
\hline 4 & $\begin{array}{l}\text { Access to cheap labour and technology } \\
\text { Basic Industry }\end{array}$ & .653 & .585 \\
\hline 1 & More demand for goods & .749 & .701 \\
\hline 2 & Basic industry goods are needed regularly & 680 & .623 \\
\hline 3 & All categories of people need them & .578 & .544 \\
\hline 4 & $\begin{array}{l}\text { Easy pricing of goods } \\
\text { Faculty Support }\end{array}$ & .508 & .510 \\
\hline 1 & ABFI are family based industries & .824 & .794 \\
\hline 2 & Family members are employed & 685 & .625 \\
\hline 3 & Avoidance of unnecessary expenses & .659 & .603 \\
\hline 4 & $\begin{array}{l}\text { Speedy development of business } \\
\text { Agriculture based District }\end{array}$ & .538 & .540 \\
\hline 1 & Location of ABFI are made locally & .779 & .742 \\
\hline 2 & Availability of raw materials & .633 & .681 \\
\hline 3 & $\begin{array}{l}\text { More assistance from district head quarters } \\
\text { Opportunity of getting more Support }\end{array}$ & 632 & .630 \\
\hline 1 & Numerous assistance to ABFIs & .847 & .740 \\
\hline 2 & Support based on standard of living & .703 & .685 \\
\hline 3 & $\begin{array}{l}\text { Category based support } \\
\text { Subsidy and Concessions }\end{array}$ & .513 & .511 \\
\hline 1 & $\begin{array}{l}\text { Numerous types of subsidy to food } \\
\text { industries }\end{array}$ & .829 & .810 \\
\hline 2 & Caste wise allocation of subsidy & .668 & .642 \\
\hline 3 & $\begin{array}{l}\text { Concession at all times } \\
\text { Limited Registration Formalities }\end{array}$ & .543 & .585 \\
\hline 1 & $\begin{array}{l}\text { Small industries require less legal } \\
\text { formalities }\end{array}$ & .743 & .795 \\
\hline 2 & Easy even to uneducated business men & .669 & .640 \\
\hline 3 & Active and friendly authorities & .580 & .532 \\
\hline 1 & & .892 & .721 \\
\hline 2 & & .725 & .630 \\
\hline 3 & & .540 & .591 \\
\hline
\end{tabular}

Source: Computed data

\section{Easy Establishment}

Establishment refers to the formation of any business. Agro based food industries are mostly found to be micro, small or medium in nature. They can be easily formed or established. Their establishment needs no large legal formalities. There is access to all the factors that are responsible for localization of industries. The factors also include latest technology. Industries, which are easily established, have a good start, promotion and establishment in the long run for a long period. 


\section{Basic Industry}

Agriculture is the base for one's life. In our life, as the basic needs (food, cloth and shelter) and comfort and luxurious kind of requirements are classified in business. Agro Based Food Industries are also classified as the basically required industry. It provides the source to all other industries, because food is a basic requirement. If food is not provided to the workers, the production ability of them may also get affected. All the agro based food industries are basic industries.

\section{Faculty Support}

It is a known fact that most of the agro based industries are family related or family based and family supported industries. It implied that many members of the family of the owners may be working as labourers or partners and the like. It results in more production with good quality and at less cost. Division of labour is the main advantage in this business.

\section{Agriculture based District}

The sample District, namely Theni District, is basically an agro based district. In this District, more than eighty percentage of the total population are engaged in one way or other, business which is agriculture in nature or agro based, agro related, agro supported and the like. There is a weekly market which is second in Tamil Nadu. All categories of agricultural operations are carried out in this District. The peculiarity of this district is that almost all factors of production are cheap in the district.

\section{Opportunity of getting more Support}

As the district is agriculture oriented, there is an opportunity of getting more support from all factors of production. There are many schemes created by the Government of India and Tamil Nadu in order to help all sectors in general and agriculture in particular. The agriculture oriented businesses are helped categorically in many respects.

\section{Subsidy and Concession}

Subsidy and concession are different in nature. Subsidy is granted to an industry as a whole which is considered essential in the national interest. Concession is basically a motivational force which makes a person take a decision which he might not have taken otherwise. It is also possible that the economic concession, both financial and non financial, pushes the respondents towards decisive action. Different types of concession are given to obtain different results. It may be in the form of loan, interest free time and the like.

\section{Limited Registration Formalities}

Every business has to be incorporated or registered with the Government. Exemptions are there. Almost all agro based businesses need to be registered. But the formalities differ from role trader to partnership to joint stock companies to trust accounts and cooperative form of business. The legal registration formalities in case of agro based food industries are limited, easy and less complicated in nature. The causes under different variables that are motivating the respondents to ABFIs are presented in Table 2.

\section{Motivating Factors by the Respondents}

The factor analysis of the twenty one attributes relating to the factors motivating the respondents of agro based food industries is presented in Table 3. 
TABLE 3

Motivating Factors by the Respondents to Agro Based Food Industries

\begin{tabular}{|c|c|c|c|c|}
\hline Sl. No & Factor & Eigen Value & $\begin{array}{l}\text { Percentage } \\
\text { of Variance }\end{array}$ & $\begin{array}{l}\text { Cumulative } \\
\text { Percentage } \\
\text { of Variance }\end{array}$ \\
\hline $\begin{array}{l}1 . \\
2 . \\
3 . \\
4 . \\
5 . \\
6 .\end{array}$ & $\begin{array}{l}\text { Easy Establishment } \\
\text { Basic Industry } \\
\text { Faculty Support } \\
\text { Agriculture based District } \\
\text { Opportunity of getting more } \\
\text { support } \\
\text { Subsidy and Concession }\end{array}$ & $\begin{array}{l}3.5841 \\
2.5903 \\
1.9060 \\
1.8750 \\
\\
1.4768 \\
1.3298\end{array}$ & $\begin{array}{l}19.9 \\
14.4 \\
10.6 \\
10.4 \\
\\
8.2 \\
7.4\end{array}$ & $\begin{array}{l}19.9 \\
34.3 \\
44.9 \\
55.3 \\
\\
63.5 \\
70.9\end{array}$ \\
\hline
\end{tabular}

Source: Computed data

Kaisar-Meyer-Olikin measures of sampling adequacy $=0.441$

Bartlett's Test of Sphericity: Chi-Square

$$
\begin{aligned}
& =1232.753 \\
& =290 \\
& =0.000
\end{aligned}
$$$$
\text { Degrees of freedom }
$$

Significance

It is observed from Table 3 that the six factors were extracted out of the twenty one attributes. These factors account for about 70.9 per cent of the variance in the data. The Eigen value for the first factor, 'Easy Establishment' is 3.5841, which indicates that the factor contains much higher information than the other factors. The first factor 'Easy Establishment' provides the maximum to the factors motivating the respondents in the study area.

It is a very important factor because the respondents decide on the basis of every establishment. The second ranking factor is 'Basic Industry' which had an Eigen value of 2.590, followed by 'Faculty Support' with 1.906, 'Agriculture based District' with 1.875, 'Opportunity of getting more support' with 1.476, 'Subsidy and Concession' with 1.330 'Limited Registration Formalities' with 0.911, and 'Availability of Human Resource' with a least Eigen value of 0.700 .

\section{Relationship between Selection Factors and Factors Motivated}

After finding the factors involved in motivating the respondents the next step is to find the relationship between the factors and the influence on the respondents in the study area. The Multiple Regression Analysis has been carried out to identify the relationship between the factors and the overall factors motivating the respondents which takes the following form Whereas

$$
\log y=\log b_{0}+b_{1} \log X_{1}+b_{2} \log X_{2}+
$$

$$
+b_{y} \log X_{y}+e^{u}
$$

$\begin{array}{lll}\mathrm{Y}_{\mathrm{N}} & - & \text { Overall score on factors influencing the respondents } \\ \mathrm{X}_{1} & - & \text { Easy Establishment } \\ \mathrm{X}_{2} & - & \text { Basic Industry } \\ \mathrm{X}_{3} & - & \text { Faculty Support } \\ \mathrm{X}_{4} & - & \text { Agriculture based District } \\ \mathrm{X}_{5} & - & \text { Opportunity of getting more support } \\ \mathrm{X}_{6} & - & \text { Subsidy and Concession } \\ \mathrm{X}_{7} & - & \mathrm{b}_{0}, \mathrm{~b}_{1}, \mathrm{~b}_{2}, \ldots \ldots \ldots \mathrm{b}_{\mathrm{y}} \text { are parameters of independent }\end{array}$




$\begin{array}{lll} & & \text { variable to be estimated } \\ \mathrm{b}_{0} & - & \text { Regression Constant } \\ \mathrm{e} & - & \text { Error term }\end{array}$

In order to term the significance of the estimated parameters $b_{0}, b_{1}, b_{2} \ldots \ldots b_{y}$, t-test of the following formula has been used,

$$
\mathrm{t}=\mathrm{b}_{1} / \mathrm{seb}_{1}
$$

where $\operatorname{Seb}_{1}=$ Standard error of $b_{1}$

The regression co-efficient of the independent variables has been estimated and the results are shown in Table 4.

\section{TABLE 4}

The Impact of Motivating Factors on the Respondents towards Agro Based Food Industries

\begin{tabular}{|c|l|c|c|c|c|}
\hline $\begin{array}{c}|c| \\
\text { Sl. } \\
\text { No. }\end{array}$ & Factor & Notation & $\begin{array}{c}\text { Elasticity of } \\
\text { co-efficient }\end{array}$ & $\begin{array}{c}\text { Standard } \\
\text { Error }\end{array}$ & 't' Value \\
\hline 1. & $\begin{array}{l}\text { Overall Scores on decision } \\
\text { making }\end{array}$ & $\mathrm{Y}$ & - & & \\
\hline 2. & Constant & $\mathrm{b}_{\mathrm{o}}$ & $15.826^{* *}$ & 0.530 & 23.65 \\
\hline 3. & Easy Establishment & $\mathrm{X}_{1}$ & $0.756^{* *}$ & 0.011 & 6.541 \\
\hline 4. & Basic Industry & $\mathrm{X}_{2}$ & $0.0719^{\mathrm{NS}}$ & 0.085 & 0.610 \\
\hline 5. & Faculty Support & $\mathrm{X}_{3}$ & $0.174^{\mathrm{NS}}$ & 0.084 & 0.490 \\
\hline 6. & Agriculture based District & $\mathrm{X}_{4}$ & $0.0276^{\mathrm{NS}}$ & 0.142 & 0.081 \\
\hline 7. & $\begin{array}{l}\text { Opportunity of getting more } \\
\text { support }\end{array}$ & $\mathrm{X}_{5}$ & $0.1040^{* *}$ & 0.316 & 7.312 \\
\hline 8. & Subsidy and Concession & $\mathrm{X}_{6}$ & $0.324^{* *}$ & 0.110 & 4.511 \\
\hline
\end{tabular}

Source: Computed data.

$$
\begin{array}{lll}
\mathrm{R}^{2} & = & 0.80 \\
\mathrm{~F}-T e s t & = & 1432.821 \\
* * & - & \text { Significant at one per cent level } \\
\mathrm{NS} & - & \text { Not Significant }
\end{array}
$$

It is evident from Table 4 that among the various factors analysed, factors like Easy Establishment, Opportunity of getting more support, Subsidy and Concession, Limited Registration Formalities and Availability of Human Resource have proved to be significant at one per cent and factors like Basic Industry, Faculty Support and Agriculture based District are not significant.

The $\mathrm{R}^{2}$ has been 0.80 and the value of the $\mathrm{F}$ test was 1432.821 .

It could be inferred from Table 4 that the 'Easy Establishment' was significantly influenced by the level of decision making ability by agro based food industries. One per cent increase in the easy environment made available to the respondents, keeping all other factors constant, would increase the overall factors motivating the respondents towards agro based food industries by 0.756 per cent from its mean level.

It could also be inferred from Table 4 that the 'Opportunity of getting more support' significantly influenced by the level of decision making ability by agro based food industries respondents. One per cent increase in the level of opportunity of getting more support made available to the respondents, keeping all other factors constant, would increase the overall factors motivating 
behaviour of the respondents towards agro based food industries by 0.1040 per cent from the mean level.

Motivation was also influenced by the factor 'Subsidy and Concession'. The co-efficient Subsidy and Concession was 0.324 which was significant at one per cent increase in the Subsidy and Concession. This shows that one per cent opportunity would increase the overall factors motivating respondents towards agro based food industries by 0.309 per cent from the mean level.

\section{Summary} They are

Six factors motivating the respondents towards agro based food industries were selected.

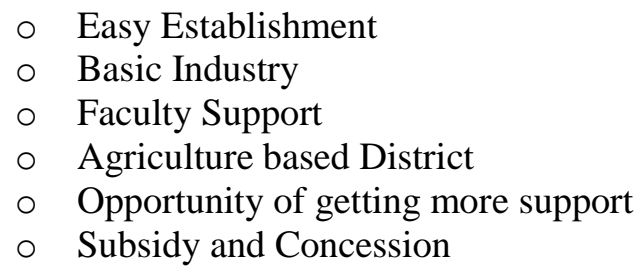

Factor analysis was applied. Each factor had more than one variable. Each variable was expressed as a linear combination of the underlying factors. The amount of variance than a variable shares with all the other variables included in the analysis was referred to as communality. Among all the attributes that are formed under each factor there was high association. There are some other requirements to the ABFIs, when these things are provided to them in some more attractive manner, the ABFIs may feel happy.

\section{Reference}

1. Kamta Prasad (2000), Poverty alleviation shift in Paradigm, Kurushetra, 50(1).

2. Nair B. C. and Oscar D. Melo, 2007, "Food Processing Industry: A catalyst to Goa's ailing agricultural sector". Southern Economist, August.1, pp. 17 - 19.

3. Raghuramaiah. B.., "Indian food Regulations in the Global Context" - Indian Food Industry, Volume. 20, No.2, 2001, pp.20-23.

4. Ramanujan K.N. (2003), Agro- Processing industry in Economic Development, Kisan World, 30(1).

5. Reddy Y.G. (2001), Role of Melas in marketing of Agro Industrial products, Research Highlights, NIRD, Hyderabad, June 2001, p.70. 